\title{
Analysis of The Effect Of Financial Distress Conditions On Activity / Efficiency Ratios In Manufacturing Companies In Indonesian Stock Exchange During The Covid Period
}

\author{
Aryono Yacobus ${ }^{1}$, Hasa Nurrohim KP1 \\ ${ }^{1}$ Universitas Pembangunan Nasional " Veteran" Yogyakarta
}

\begin{abstract}
The study aims to retest the financial ratios derived from balance sheets, income statements, and cash flow statements. This research is also to find out the effect of financial distress conditions on the activities of companies in the manufacturing industry sector during the Covid period. Is there an influence on financial to activity ratios for companies experiencing financial distress during the covid period?. This study used logistical statistical analysis while to determine whether the company experienced financial distress or not, using Altman's Z Score value analysis. After testing, it was found that the ratio of cash position and activity ratio had a significant effect on companies experiencing financial distress.
\end{abstract}

Keywords: Financial Ratios, Financial Distress, Altman's Z Score

\begin{abstract}
This is an open access article under the CC-BY-NC license
\end{abstract}
\section{INTRODUCTION}

\section{Background Problems}

Economic crises involving companies and the financial sector in developing countries, especially in Asia, from 1997 to 1998, resulting in poor industrial conditions in Indonesia. This condition is still felt at the moment because the economy has not developed as well as it used to. This condition is mainly experienced by the manufacturing industry sector, which is experiencing very bad financial difficulties. The destruction of this sector is due to the decline in people's purchasing power and sluggish domestic economic activities that make the number demand industrial products manufactured decrease (Brahmana, 2004). In addition, the interest rate on loans is high, limited credit from banks, the high cost of imported raw materials, and the rejection of Letters of Credit (L/C) issued by national banks and overseas banks caused many companies in the manufacturing industry sector to experience financial difficulties and even bankruptcy.

Bankruptcy can be caused by two things, namely: first, economic failure related to the imbalance between income and expenditure; Second, the company cannot afford to pay its obligations at maturity. Investors and creditors, before investing in a company, will usually see first the financial condition of the company. Therefore, analysis and prediction of the financial condition of a company is very important and should not be ignored.

Companies that experience a decline in financial condition before bankruptcy or liquidation are often called experiencing financial distress conditions (Plat and Plat, 2002). Financial distress occurs because the company is unable to manage and maintain the stability of the company's financial performance, which stems from a failure to promote the products it makes, which causes a decrease in 
RSF Conference Series: Business, Management and Social Sciences, Vol. 1 (3), 9-22

\section{Analysis of The Effect Of Financial Distress Conditions On Activity / Efficiency Ratios In Manufacturing Companies In Indonesian Stock Exchange During The Covid Period \\ Aryono Yacobus, Hasa Nurrohim KP}

sales so that revenue decreases which allow the company to experience operating losses and net losses for the current year (Brahmana, 2004) from the losses incurred will result in capital deficiencies caused by a decrease in the value of the balance of profits used to pay dividends, total equity as a whole is also in deficiency. Then one day, the total liabilities of the company will exceed the total assets it has. If the company is unable to get out of this condition, then the company will experience bankruptcy.

Identification of financial distress can be made using the analysis of the company's financial statements through existing financial ratios. Several studies that use financial ratios to predict a company's financial distress have been conducted, including Foster (1986), Lau (1987), Plat and Plat (2002), Luciana and Kritijadi (2003), Brahmana (2004), and Luciana (2006). The financial ratio used in plat and plat research (2002) is the financial ratio derived from information in balance sheets and income statements. Similar research Luciana (2006) was conducted by adding financial ratios derived from cash flow statement information to predict the financial distress condition of the company. Brahmana (2004) uses unadjusted financial ratios based on its industry and rating the reputation of auditors based on the total number of assets audited by the auditor.

\section{Problem Formulation.}

1. Is there a variable effect of financial ratio to activity/efficiency ratio in companies that experience financial distress conditions in companies in the manufacturing sector during the covid?

2. What is the dominant factor of financial ratio in companies that experience financial distress in companies in the manufacturing sector during ms covid?

\section{LITERATURE REVIEW}

\section{Financial Statements}

Accounting is a service activity that serves to provide qualitative information, usually in a monetary form, about the units of economic units intended and used in economic decision-making. Accounting can also be referred to as financial reporting. Below are some understandings of financial statements, including the following:

1. Financial statements are the final results of the accounting process that can be used as a means of communication between financial data or the activities of a company with parties concerned with the data or activities of the company (Munawir. S, 1995).

2. Financial statements are an overview of the financial state of a company where the balance sheet reflects the value of assets, debt, capital itself at any given time, and the income statement is usually the result of financial statements over one year (Riyanto. Bambang, 1995).

3. Financial statements are one of the important sources of information, such as company market share information, management quality, and others. There are three types of financial statements, namely: balance sheet, income statement, and cash flow statement. In addition to the report, there are also supporting reports, such as reports of retained earnings, reports of capital changes (Hanafi. M and Halim. A, 1996).

4. A financial statement is a report that describes the results of an accounting process used as a means of communication between financial data or company activities with parties concerned with such data or activities (Ridwan. S and Inge Barlian, 2001).

5. Financial statements are a summary of a registrar process, a summary of financial transactions that occurred during the financial year in question (Munawir. S, 1995). 
RSF Conference Series: Business, Management and Social Sciences, Vol. 1 (3), 9-22

\section{Analysis of The Effect Of Financial Distress Conditions On Activity / Efficiency Ratios In Manufacturing Companies In Indonesian Stock Exchange During The Covid Period \\ Aryono Yacobus, Hasa Nurrohim KP}

The financial statements in this study are used to predict the financial distress conditions of manufacturing industry companies listed on the Indonesia Stock Exchange.

\section{Type ratio}

The types of company ratios derived from balance sheets and income statements, and cash flow statements are as follows (Harahap, 1997):

\section{Rentability}

The ratio of rentability or also called profitability, describes the ability of the company to earn profits through all existing capabilities and sources such as sales, cash, capital, number of employees, number of branches, and so on. The type of rentability ratio used is the ratio of profit margin ( profit margin).

\section{Liquidity}

Liquidity ratios describe a company's ability to settle its short-term liabilities. The liquidity ratio used is the current ratio.

\section{Activity/Efficiency Ratio}

This ratio describes the activities carried out by the company in carrying out its operations, both in sales, purchasing, and other activities. Shows a company that earns more profit than other companies on the same resource. The activity ratio used is total asset turnover.

\section{Profitability}

The profitability ratio indicates the result of some wisdom and decisions. The profitability ratio used is the rate of return on assets.

\section{Financial Leverage}

Financial leverage is the level of long-term creditor protection and investment. The ratio used is the ratio of debt to assets.

Cash position

The ratio used is the ratio of cash to current debt.

\section{Growth}

This ratio illustrates the percentage growth of the company's posts from year to year. The ratio used is a ratio that reflects the increase or percentage growth in net income

\section{Operation Activities}

Operating activities are the main generating activities of corporate revenue (principal revenueproducing activities) and other activities that are not investment activities and funding activities.

\section{Investment Activities}

Investment activity reflects cash receipts and expenses for resources that aim to generate future income and cash flow. 
RSF Conference Series: Business, Management and Social Sciences, Vol. 1 (3), 9-22

Analysis of The Effect Of Financial Distress Conditions On Activity / Efficiency Ratios In Manufacturing Companies In Indonesian Stock Exchange During The Covid Period

Aryono Yacobus, Hasa Nurrohim KP

\section{Funding Activities}

Funding activities are activities that result in changes in the amount and composition of the company's odal and loans.

\section{Understanding financial distress}

The performance condition of a company can be seen from the financial statements owned. Financial statements are a source of information for parties who have an interest in a company. Users of financial statements can assess a company whether it is in good or bad condition. Financial distress is financial hardship beginning when a company is unable to pay off its obligations to creditors or an inability to pay off debts that show negative performance and liquidity problems (Brigham and Gapenski, 1995).

\section{Previous research}

Platt and Platt (2002) conducted a study of 24 companies that experienced financial distress and 62 companies that did not experience financial distress, using the logit model, they sought to determine the most dominant financial ratio to predict the presence of financial distress. The findings of this study are: variable EBITDA / sales, current assets / current liabilities, and cash flow growth rate has a negative relationship to the possibility of companies that will experience financial distress. While the variable net fixed assets / total assets, long-term debt/ equity, and notes payable/total assets have a positive relationship to the possibility that the company will experience financial distress. The greater this ratio, the more likely the company is to experience financial distress.

Luciana and Meliza (2003) conducted researched the financial distress condition of a company represented by three groups of companies and one group of control companies as a comparison. The four groups of companies are the first group represented by companies that experience negative net income for two consecutive years; the second group is represented by companies that experienced negative net income and negative equity book value for two consecutive years; b. the third group is represented by a delisted company, and the fourth group is represented by companies that are still active and do not experience negative net income for two consecutive years. This study provides evidence that the ratio of net income / total assets, shareholder equity / total assets, retained earnings / total assets, and total debt/total assets can be used to predict the probability of companies experiencing financial distress conditions.

Luciana (2004) also conducted a study of 81 companies with details of 43 companies that did not experience financial distress, 14 companies that experienced financial distress in the first group (companies that experienced negative net income for two consecutive years), and 24 companies that experienced financial distress in the second group (companies that experienced negative net income and negative equity book value for two consecutive years). As a control, a healthy company was selected in 2000-2001. The variables used in this study are the financial ratio of income statements, balance sheets, and cash flows as independent variables. While the dependent variable used is the condition of the company's financial distress, which is a category variable, which is 0 for healthy companies, 1 and 2 for companies experiencing financial distress. The findings of this study are: current assets/current liabilities (CACL), working capital/ total assets (WCTA), current assets/ total assets (CATA), (NFTA), sales / total assets (STA), net income / total assets (NITA), net income / equity (NIEQ). total liabilities / total assets (TLTA), cash / current liabilities (CASHCL), cash / total assets (CASHTA), cash flow / current liabilities (CFFOCL), cash flow / total liabilities (CFFOTL), cash flow / total sales (CFFOTS) and cash flow / total assets (CFFOTA) between companies experiencing financial distress conditions. Variable total liabilities / total 
RSF Conference Series: Business, Management and Social Sciences, Vol. 1 (3), 9-22

Analysis of The Effect Of Financial Distress Conditions On Activity / Efficiency Ratios In Manufacturing Companies In Indonesian Stock Exchange During The Covid Period

Aryono Yacobus, Hasa Nurrohim KP

assets (TLTA), operating activity / total assets, Operating activity / total debt have a negative relationship to the possibility that the company will experience financial distress. The lower this ratio, the higher the probability of the company experiencing financial distress conditions (both companies that experience negative net income and negative equity book value for two consecutive years and companies that experience negative net income and negative equity book value for two consecutive years). While the variable of operating activity / current debt, current assets / total assets have a positive relationship to the possibility of companies that will experience financial distress conditions. The higher this ratio, the higher the likelihood of the company experiencing financial distress conditions (both companies that experience negative net income and negative equity book value for two consecutive years and companies that experience negative net income and negative equity book value for two consecutive years).

\section{Hypothesis}

Based on the analysis and findings of previous studies, the hypotheses of this study are:

1. There is a variable influence of financial ratio to activity/efficiency ratio in companies experiencing financial distress conditions in companies in the manufacturing sector during the covid period.

2. The dominant factor of financial liquidity ratio in companies experiencing financial distress in companies in the manufacturing sector during the covid period.

\section{RESEARCH METHOD}

\section{Sample selection}

The population used in this study were all companies listed on the Indonesia Stock Exchange during 2019-2020. Sampling is done using purposive sampling with the following sample selection criteria:

1. Manufacturing companies that for three consecutive years experienced declining sales.

2. Manufacturing companies that for three consecutive years experienced a decreased net income.

\section{Data Sources and Data Collection Techniques}

There are several data sources and data collection techniques conducted in this study, namely: financial statements, in the form of balance sheet statements, income statements, and cash flow statements for the period 2019-2020, obtained from the book ICMD (Indonesian Capital Market Directory).

\section{Operational Definition}

In this study, several related variables were used, including:

\section{Dependent Variable}

This variable describes the activities carried out by the company in carrying out its operations, both in sales, purchasing, and other activities. The activity/efficiency ratio used is as follows:

1. The ratio of working capital to total assets

2. The ratio of earnings is resistant to total assets.

3. The ratio of pre-tax earnings to total assets

4. Market equity to book value of debt ratio

5. The ratio of sales to total assets 
Using these five ratios, included in Altman's statement, the value Z Score will be found. The value of The Z Score is to determine the company that is experiencing financial distress or non-financial distress. For companies that enter financial distress will be given the number 1 (Value Z Score less than 3), while companies that enter the non-financial distress are given a number 0 (Value Z Score equals or more than $3)$.

\section{Independent Variables}

The financial ratio of the income statement and balance sheet information used in this study is as follows:

1. Rentability ratio

The ratio of rentability used is the profit margin. Profit margin is a comparison between net operating income with net sales between net income with sales (Riyanto, Bambang; 1995).

$$
\text { Net Profit Margin }=\frac{\text { Net } \text { Income }}{\text { Sales }}
$$

This ratio figure shows how much percentage of net income is obtained from each sale. The greater this ratio, the better because it is considered the company's ability to make a profit is quite high.

\section{Liquidity Ratio}

Liquidity ratios describe a company's ability to settle its short-term liabilities. The liquidity ratio used is:

$$
\text { Working Capital to Assets Ratio }=\frac{\text { WorkingCapital }}{\text { AssetsTotal }}
$$

This ratio figure indicates how much working capital or assets are obtained from each total asset. The greater this ratio, the better because the company's ability to settle its short-term liabilities is high.

\section{Profitability Ratio}

The profitability ratio indicates the result of some wisdom and decisions. The profitability ratio used is as follows:

$$
\text { Rate of Return on Assets }=\frac{\text { NetIncome }}{\text { AssetsTotal }}
$$

This ratio shows how far a company's ability to make a profit from the use of all its assets is. The higher this ratio, the better.

\section{Financial Leverage Ratio}

Financial leverage is the level of long-term creditor protection and investment. Financial leverage is a ratio intended to measure how far a company's assets are financed with debt. The financial leverage ratio used is as follows:

$$
\text { Debt to Total Assets Ratio }=\frac{\text { Debt }}{\text { AssetsTotal }}
$$


This ratio indicates the extent to which debt can be covered by assets. The larger the ratio, is safer (solvable). It can also be read how much debt is compared to assets. To be safe, the portion of the debt to assets must be smaller.

5. Cash Position Ratio

The ratio of cash positions used is the ratio of cash to current debt.

$$
\text { Cash Position Ratio }=\frac{\text { Cash }}{\text { CurrentDebt }}
$$

This ratio indicates the extent to which cash can be covered by current assets. The larger the ratio, is safer (solvable). It can also be read how much cash is compared to assets. To be safe, the portion of cash to current debt must be larger.

\section{Growth Ratio}

This ratio illustrates the percentage growth of the company's posts from year to year. The ratio used is a ratio that reflects an increase in net income or a percentage growth in net income. The growth ratio used is as follows.

$$
\text { Sales Growth Ratio }=\frac{\text { Sales }_{t}-\text { Sales }_{t-1}}{\text { Sales }_{t-1}}
$$

This ratio indicates the extent to which sales growth can be covered by Sales $t-1$. The larger the ratio, is safer (solvable).

The financial ratio of the cash flow statement information used in this study is the Operating Activity Ratio

Operating activities are the main revenue-generating activities of the company and other activities that are not investment activities and funding activities. Operating activities include:

Net Cash Flow from Operating Activities on Sales

$$
=\frac{\text { Net Cash Flow from Operating Activities }}{\text { Sales }}
$$

\section{FINDINGS AND DISCUSSION}

\section{Finding}

Hypothesis testing on this study used the SPSS (Statistical Package for Social Science) program, using logistic regression analysis tools.

\section{Assessing the Fit Model.}

Assessing the overall model fit test is a test to assess the entire regression model. Overall fit tests are tested using -2loglikelihood or omnibus tests. Value - 2loglikelihood shows match numbers based on the iteration model performed. The value of -2loglikelihood at the beginning and the end indicates the same value. Based on the output, there is no second difference of - 2 LogL, so it is concluded that the addition of free variables to the model does not improve the fit model. 
RSF Conference Series: Business, Management and Social Sciences, Vol. 1 (3), 9-22

\section{Analysis of The Effect Of Financial Distress Conditions On Activity / Efficiency Ratios In Manufacturing Companies In Indonesian Stock Exchange During The Covid Period \\ Aryono Yacobus, Hasa Nurrohim KP}

Table 1. Overall Model Fit Test Results

\begin{tabular}{|l|c|}
\hline \multicolumn{1}{|c|}{ Description } & Value \\
\hline-2 loglikelihood at the beginning (block number $=0$ ) & 236.175 \\
\hline-2 loglikelihood at the end (block number $=1$ ) & 236.175 \\
\hline
\end{tabular}

Based on Table 5.1 above, the value of -2loglikelihood at the beginning (block number $=0$ ) is 236,175 . This model only includes constants, significant at $\alpha=5 \%$, meaning that the model with only constants is not fit with the data. At the value of -2likelihood at the end (number block =1), 236, 175. This model includes constants and seven free variables, significant at $\alpha=5 \%$, meaning that the model is fit with data.

\section{Assessing the Feasibility of regression models}

Hosmer and Lemeshow's Goodness of Fit Test tested the hypothesis of whether empirical data matched the model (model fit) or according to the model (there is no difference between the model and the data so that the model can be said to be fit).

H0: The model in which the data is difficult if the Hosmer and Lemeshow Goodness-of-fit test statistic > 0.05

Ha: The model that is in question is fit with data if the value of Hosmer and Lemeshow Goodness-of-fit test statistic $<0.05$

Table 2 Results Holsmer and LemeshowTest

\begin{tabular}{|l|r|r|c|}
\hline \multicolumn{4}{|c|}{ Hosmer and Lemeshow Test } \\
\hline Step & Chi-square & df & Sig. \\
\hline 1 & 4.623 & 8 & .797 \\
\hline
\end{tabular}

Based on Table 5.2 above, it can be explained that the results of the Hosmer and Lemeshow Test are 4,623 , with a probability of significance of 0.797 . If compared to $\alpha=5 \%$, then the result is greater, 0.797 $>0.05$.

This means that the model is acceptable and the $\mathrm{H} 0$ acceptable. The logistic regression model in this research can be used to predict the probability of financial distress in manufacturing companies listed on the Indonesia Stock Exchange from 2019 to 2020.

\section{Determinant Coefficient}

Cox \&Snell Square is a size that mimics R2 in multiple regression. Nagelkerke R Square is a modification of the Cox coefficient \& snell square. So Nagelkerke R Square is intended to know the magnitude of the predictive variables of independent variables against dependents can be traced to the value, between 0 to 1 . The coefficient of determination at its core measures how far the model's capabilities on independent variables, namely Rentability, Liquidity, Profitability, Financial Leverage, Cash Position, Growth, Activity together describe the variation of bound variables (financial distress). The results of the test with SPSS on this test can be seen in the following table: 
RSF Conference Series: Business, Management and Social Sciences, Vol. 1 (3), 9-22

\section{Analysis of The Effect Of Financial Distress Conditions On Activity / Efficiency Ratios In Manufacturing Companies In Indonesian Stock Exchange During The Covid Period \\ Aryono Yacobus, Hasa Nurrohim KP}

Table 3. Discriminant Coefficient Results (Nagelkerke R Square)

\begin{tabular}{|c|c|c|c|}
\hline \multicolumn{4}{|c|}{ Model Summary } \\
\hline Step & $\begin{array}{c}-2 \text { Log } \\
\text { likelihood }\end{array}$ & $\begin{array}{l}\text { Cox \& Snell R } \\
\text { Square }\end{array}$ & $\begin{array}{c}\text { Nagelkerke R } \\
\text { Square }\end{array}$ \\
\hline 1 & $201.545^{\mathrm{a}}$ & 108 & .200 \\
\hline
\end{tabular}

Based on Table 5.3 above, the Nagelkerke R Square value of 0.200 means that dependent variables can be explained by independent variables by $20 \%$, while the remaining $80 \%$ is explained by other variables beyond the variables in this study. This shows that together the variation of free variables can explain the variation of financial distress variables by $20 \%$.

\section{Matrix Classification}

The classification matrix shows the predictive power of regression models to predict a company's likelihood of experiencing financial distress.

Table 4. Classification Matrix Results

\begin{tabular}{|c|c|c|c|c|c|}
\hline \multicolumn{6}{|c|}{ Classification Tables } \\
\hline & \multirow{3}{*}{\multicolumn{2}{|c|}{ Observed }} & & Predic & \\
\hline & & & Finar & stress & Percentage \\
\hline & & & 0 & 1 & Correct \\
\hline \multirow[t]{3}{*}{ Step 1} & \multirow[t]{2}{*}{ FinancialDistress } & 0 & 6 & 34 & 15.0 \\
\hline & & 1 & 3 & 259 & 98.9 \\
\hline & \multicolumn{2}{|c|}{ Overall Percentage } & & & 87.7 \\
\hline
\end{tabular}

Based on Table 5.4, the prediction of companies experiencing financial distress is as many as 259 companies, with a model accuracy of $98.9 \%$. While the predictive power of regression models to predict the possibility of companies not experiencing financial distress by $15 \%$, there are six companies.

The overall predictive power of the regression model is $87.7 \%$, meaning that independent variables can statistically predict regression models by $87.7 \%$.

\section{Simultaneous Hypothesis Test}

The Omnibus Test of Model Coefficient is conducted to test significance simultaneously in logistic regression analysis. Testing is done to test whether independent variables in research have an effect together on dependent variables.

The way to know the results of simultaneous tests is to look at the results of logistic regression by looking at the significance value. If the significance value is $<0.05$, then $\mathrm{HO}$ is accepted, but if the significance value is $<0.05$, then $\mathrm{H} 0$ is rejected, or Ha is accepted. 
RSF Conference Series: Business, Management and Social Sciences, Vol. 1 (3), 9-22

Analysis of The Effect Of Financial Distress Conditions On Activity / Efficiency Ratios In Manufacturing Companies In Indonesian Stock Exchange During The Covid Period

Aryono Yacobus, Hasa Nurrohim KP

Table 5. Simultaneous Hypothesis Test Results

\begin{tabular}{|l|l|l|l|l|}
\hline \multicolumn{5}{|c|}{ Omnibus Tests of Model Coefficients } \\
\hline \multicolumn{2}{|c|}{} & Chi-square & df & Sig. \\
\hline \multirow{3}{*}{ Step 1 } & Step & 34.630 & 7 & .000 \\
\cline { 2 - 5 } & Block & 34.630 & 7 & .000 \\
\cline { 2 - 5 } & Model & 34.630 & 7 & .000 \\
\hline
\end{tabular}

Based on Table 5.5, it can be seen that the sig value of the model is 0.000 . This value is less than the value of $\alpha=5 \%$. So it can be indicated that independent variables together affect the probability of financial distress.

\section{Partial Hypothesis Test}

To test partial hypotheses used a logistic regression test was performed against all free variables. The test results are as follows:

Table 6. Partial Hypothesis Test Results

\begin{tabular}{|c|c|c|c|c|c|c|c|c|c|}
\hline \multicolumn{10}{|c|}{ Variables in the Equation } \\
\hline & & \multirow[b]{2}{*}{ B } & \multirow[b]{2}{*}{ S.E. } & \multirow[b]{2}{*}{ Wald } & \multirow[b]{2}{*}{$\mathrm{df}$} & \multirow[b]{2}{*}{ Sig. } & \multirow[b]{2}{*}{$\operatorname{Exp}(B)$} & \multicolumn{2}{|c|}{$\begin{array}{c}\text { 95\% C.I.for } \\
\text { EXP(B) }\end{array}$} \\
\hline & & & & & & & & Lower & Upper \\
\hline \multirow[t]{8}{*}{ Step $1^{\mathrm{a}}$} & Rentabilitas & .000 & .000 & 1.677 & 1 & .195 & 1.000 & 1.000 & 1.000 \\
\hline & Liquidity & .000 & .000 & 1.950 & 1 & .163 & 1.000 & 1.000 & 1.000 \\
\hline & Profitability & .000 & .000 & 3.463 & 1 & .063 & 1.000 & 1.000 & 1.000 \\
\hline & Leverage & .000 & .000 & .496 & 1 & .481 & 1.000 & 1.000 & 1.000 \\
\hline & Posisi_Kas & -.001 & .000 & 13.401 & 1 & .000 & .999 & .999 & 1.000 \\
\hline & Pertumbuhan & .000 & .000 & .021 & 1 & .885 & 1.000 & 1.000 & 1.000 \\
\hline & Aktifitas & . 000 & .000 & 9.883 & 1 & .002 & 1.000 & 1.000 & 1.000 \\
\hline & Constant & 3.221 & .484 & 44.255 & 1 & .000 & 25.054 & & \\
\hline
\end{tabular}

Based on Table 5.6, it can be arranged logistic regression equation, as follows:

$$
\mathrm{FD}=3,221+0.000 \mathrm{X} 1+0.000 \mathrm{X} 2+0.000 \mathrm{X} 3+0,000 \mathrm{X} 4-0,000 \mathrm{X} 6+0.000 \mathrm{X} 7
$$

From the logistic regression equation, it can be known that the company's log of odds is positively related to Rentability, Liquidity, Profitability, Leverage, Growth, Activity. While the cash position is negatively related.

\section{The Effect of Rentability on Financial Distress.}


RSF Conference Series: Business, Management and Social Sciences, Vol. 1 (3), 9-22

Analysis of The Effect Of Financial Distress Conditions On Activity / Efficiency Ratios In Manufacturing Companies In Indonesian Stock Exchange During The Covid Period

Aryono Yacobus, Hasa Nurrohim KP

Based on the table above, the regression coefficient results of the rentability variable of 0.000 with a significance value of 0.195 and a log-odds value of 1,000 so that it can be interpreted that the rentability variable has no significant effect on the probability of financial distress because the significance value of $0.195>0.05$

Rentability has a positive relationship to financial distress, so it can be interpreted that the higher the level of rent obtained, the higher the tendency of the company to experience financial distress.

\section{The Effect of Liquidity on Financial Distress}

Based on the table above, the result of the regression coefficient of liquidity variable of 0.000 with a significance value of 0.163 and a log-odds value of 1,000 can be interpreted so that the liquidity variable has no significant effect on the probability of financial distress because the significance value of $0.163>$ 0.05 .

Liquidity has a positive relationship to financial distress, so it can be interpreted that the higher the level of liquidity obtained, the higher the tendency of the company to experience financial distress.

\section{The Effect of Profitability on Financial Distress}

Based on the table above, the result of the regression coefficient of the profitability variable is 0.000 with a significance value of 0.063 , and the log odds value of 1,000 can be interpreted so that the profitability variable has no significant effect on the probability of financial distress because the significance value of $0.063>0.05$.

Profitability has a positive relationship to financial distress, so it can be interpreted that the higher the level of profitability obtained, the higher the tendency of the company to experience financial distress.

\section{Influence of Financial Leverage on Financial Distress}

Based on the table above, the result of the regression coefficient of the Financial Leverage variable of 0.000 with a significance value of 0.481 and a log-odds value of 1,000 can be interpreted so that the financial leverage variable has no significant effect on the probability of financial distress because the significance value of $0.481>0.05$.

Financial leverage has a positive relationship with financial distress, so it can be interpreted that the higher the level of Financial Leverage obtained, the higher the tendency of the company to experience financial distress.

\section{Effect of Cash Position on Financial Distress}

Based on the table above, the regression coefficient of the Cash Position variable of 0.000 with a significance value of -0.001 and a log-odds value of 0.999 can be interpreted so that the Cash Position variable has a significant effect on the probability of financial distress because the significance value of $0.000<0.05$.

Cash position has a negative relationship to financial distress, so it can be interpreted that the higher the level of Cash Position obtained, the lower the tendency of the company to experience financial distress.

\section{Effect of Growth on Financial Distress}

Based on the table above, the result of the regression coefficient of the Growth variable of 0.000 with a significance value of 0.885 and a log-odds value of 1,000 can be interpreted that the Growth variable 
RSF Conference Series: Business, Management and Social Sciences, Vol. 1 (3), 9-22

Analysis of The Effect Of Financial Distress Conditions On Activity / Efficiency Ratios In Manufacturing Companies In Indonesian Stock Exchange During The Covid Period

Aryono Yacobus, Hasa Nurrohim KP

has no significant effect on the probability of financial distress because the significance value of $0.885>$ 0.05 .

Growth has a positive relationship to financial distress, so it can be interpreted that the higher the growth rate obtained, the higher the tendency of the company to experience financial distress.

\section{Effect of Activity on Financial Distress}

Based on the table above, the result of the regression coefficient of the Activity variable of 0.000 with a significance value of 0.002 and a log-odds value of 1,000 can be interpreted so that the Activity variable has no significant effect on the probability of financial distress because the significance value of $0.002<0.05$.

Activity has a positive relationship to financial distress, so it can be interpreted that the higher the level of activity obtained, the higher the tendency of the company to experience financial distress.

\section{Discussion}

Logistic Regression Analysis Methods can Predict the Probability of Financial Distress.

Chi Square's statistical results in this study have a value below 0.05 , meaning that research using this logistics model is significant. At the Hosmer and Lemeshow Goodness of Fit test value of 0.797, the value is also above 0.05 , meaning there is no difference between the model and the data so that the model can be said to be fit.

Effect of Rentability, Liquidity, Profitability, Financial Leverage, Cash Positions, Growth, and Activity on Financial Distress.

Based on the results of logistic regression tests, for variables rentability, liquidity, profitability, financial leverage, and growth turned out to have no significance to financial distress. Although the variables have a positive relationship to financial distress, this finding is in line with findings from previous studies conducted by Plat \&Plat (2002).

\section{Influence of Cash Position and Ratio of Activity to Financial Distress.}

Based on the results of logistic regression tests, cash position variables and activity ratios have a significant influence. For cash positions have a significant effect and have a negative relationship to financial distress, meaning that the higher the cash position, the smaller the risk of financial distress. This can happen because the stronger the cash position of a company, the stronger the company's ability to meet its capital and to make investments. Or it can also happen vice versa if the company's cash position is lower, the higher the risk of financial distress.

The ratio of activity also has a significant effect and has a positive direction to financial distress. This means that this condition can occur because the higher the company's activity, the higher the financial distress.

\section{CONCLUSION}

\section{Conclusion}

Based on the results of research and discussion, conclusions can be taken in this study as follows:

1. The logistic regression model in this research can be used to predict financial distress in manufacturing companies listed on the Indonesia Stock Exchange from 2019 to 2020 during the covid period. 
RSF Conference Series: Business, Management and Social Sciences, Vol. 1 (3), 9-22

\section{Analysis of The Effect Of Financial Distress Conditions On Activity / Efficiency Ratios In Manufacturing Companies In Indonesian Stock Exchange During The Covid Period \\ Aryono Yacobus, Hasa Nurrohim KP}

2. There is a common influence between Rentability, Liquidity, Profitability, Financial Leverage, Cash Position, Growth, and Activity towards Financial Distress in manufacturing companies listed on the Indonesia Stock Exchange from 2019 to 2020 during the covid period.

3. There was no effect of Rentability, Liquidity, Profitability, Financial Leverage, Growth, on Financial Distress on manufacturing companies listed on the Indonesia Stock Exchange from 2019 to 2020 during the covid period.

4. There is an influence on Cash Position and Activity to Financial Distress Ratio on manufacturing companies listed on the Indonesia Stock Exchange from 2019 to 2020 during the covid period.

\section{Further Research}

1. Increase the periodization of research data used that only uses financial data during the period of covid 19. The ability to detoxify financial distress will be better if you use long enough panel data.

2. Adding variables and ratios used can be from ratios other than those already used in this study to compare the results.

\section{REFERENCES}

Altman, Edward I. 1968. Financial Ratios, Discriminant Analysis and the Prediction of Corporate Bankruptcy, The Journal of Finance, September, Volume 23, Number 4, New York: American Finance Association.

Brahmana, Rajenda K. 2007. Identifying Financial Distress Condition in Indonesia Manufacture Industry, e-Journals Perhimpunan Pelajar Indonesia-United Kingdom, London, Oktober.

Damodaran, Aswath. 2006. The Cost of Distress: Survival, Truncation Risk and Valuation. Paper Stern School of Business January.

Fahmi, I. 2015. Introduction to Financial Management Theory and Questions of Answer. 4th Edition. Bandung: Alfabeta.

Foster, George, 1986. Financial Statement Analysis, Second Edition, New Jersey: Prentice-Hall International.

Gamayuni, R. R. 2015. The Effect of Intangible Asset, Financial Performance and Financial Policies on The Firm Value. International Journal of Scientific \& Technology Research. 4(1). p.202-212.

Ghozali, Imam. 2002. Multivariate Analysis Application with SPSS Programs. Diponegoro University Publishing Semarang.

Gujarati, Damodar. 1991. Basic econometrics. Jakarta: Erlangga.

Hanafi, M Mamduh.. dan Abdul Halim. 2003. Analysis of Financial Statements. Yogyakarta: UPP AMPYKPN.

Hanifah, 0. 2013. The Impact of Corporate Governance Structure and Financial Indicators on Financial Distress. "journal MM Undip, h. 25-53

Lau, Ling, Amy Hing, 1987. A Five States Financial Distress Prediction Model, Journal of Accounting Research, Volume 25, Number 1, Oklahoma: Blackwell Publishing Limited.

Mulyadi, 2002. Auditing, 6th Edision, Salemba Empat, Jakarta

Munawir. S. 1998. Analysis of Financial Statements. Yogyakarta: penerbit Liberty.

Platt HD, Platt MB. 2002. Predicting corporate financial distress: reflecting on choice-based sample bias. Journal of Economics and Finance 26(2):184-199.

Prastowo, Dwi dan Rifka. 2005. Analysis of Financial Statements. Yogyakarta: UPP AMP YKPN. 
RSF Conference Series: Business, Management and Social Sciences, Vol. 1 (3), 9-22

Analysis of The Effect Of Financial Distress Conditions On Activity / Efficiency Ratios In Manufacturing Companies In Indonesian Stock Exchange During The Covid Period

Aryono Yacobus, Hasa Nurrohim KP Mada.

Riyanto, Bambang. 1995. Basic Cost of The Company. Yogyakarta: Yayasan Badan Penerbit Gadjah

Sari, Ayu Kurnia. 2016. Financial Distress Analysis on Indonesia Stock Exchange Companies. Jurnal ilmiah Research Sains Vol.2 No. 2 Juni 2016

Sawirr, Agnes. 2001. Financial Performance Analysis and Financial Planning of The Company. Jakarta: PT. Gramedia Pustaka Utama.

Schuppe, Walter p (2005), "Leading a Turnaround", The Secured Lender

Sofyan Syafri Harahap. 1997. Critical Analysis of Financial Statements. Jakarta: PT Raja Grafindo Persada.

Spica, Luciana Almilia dan Meliza Silvy. 2003. Analysis of Factors Affecting a Company's Post IPO Status with Logit Multinomial Analysis. Jurnal Ekonomi dan Bisnis Indonesia (JEBI). Volume 18 no 4.

Spica, Luciana Almilia. 2006. Prediction of Financial Distress Conditions of Companies Goes Public using Logit Multinomial Analysis. Jurnal Ekonomi dan Bisnis Indonesia (JEBI). Volume 12 no 1.

Sugiyono. 2005. Business Research Methods. Bandung: Alfabeta. 